\title{
THE END OF SEX DISCRIMINATION IN EMPLOYER-OPERATED PENSION PLANS: THE CHALLENGE OF THE MANHART CASE*
}

The underlying principle of Title VII of the Civil Rights Act of $1964^{1}$ is that einployers generally must inake einployment decisions on the basis of the individual characteristics of an applicant or employee. ${ }^{2}$ Employers are prohibited under Title VII from making employment decisions on the basis of an individual's sex. ${ }^{3}$ In contrast, insurers rely on certain group characteristics, as reflected by statistically valid actuarial tables, and consequently assume that every individual in the particular group will live as long as the average member of the group. The application of such groupings permits imsurers to comply witl the underlying principle of annuities: "that the fund from which annuitants are paid should not be exhausted until the last annuitant covered by the fund dies."4 By relymg on group characteristics, msurers are able to predict the life expectancies of their annuitants with the accuracy required to comply with the principle of sufficient funding. ${ }^{5}$

Traditionally, insurers have grouped insureds for these purposes

* The author gratefully acknowledges the editorial assistance of Dean Theodore J. St. Antoine, University of Michigan Law School, in the preparation of this Note.

THE FOLLOWING CITATIONS WILL BE USED IN THIS NOTE:

Gold, Equality of Opportunity in Retirement Funds, 9 LoYOLA L.A. L. REv. 596 (1976) [hereinafter cited as Gold];

Halperin \& Gross, Sex Discrimination and Pensions: Are We Moving Toward Unisex Tables?, 30 N.Y.U. CONF. ON LAB. 235 (1977) [hereinafter cited as Halperin \& Gross].

I. 42 U.S.C. $\$ \S 2000 \mathrm{e}-2000 \mathrm{e}-15$ (1976).

2. For a more complete discussion of the principles of Title VII, see text accompanying notes 10-28 infra.

3. The statutes provides in pertinent part:

It shall be an unlawful einployment practice for an employer-(I) to fail or refuse to hire or to discharge any individual, or otherwise to discriminate against any individual with respect to his compensation, terms, conditions, or privileges of employment, because of such individual's .... sex .....

42 U.S.C. \& 2000e-2(a)(I) (1976).

It shall be an unlawfuI employment practice for an employer-(2) to limit, segregate, or classify his employees or applicants for employment in any way which would deprive any individual of employment opportunities or otherwise adversely affect his status as an einployee, because of such individual's . . . sex....

Id. $\$ 2000 \mathrm{e}-2(\mathrm{a})(2)$.

4. EEOC v. Colby College, 439 F. Supp. 631,634 (D. Me. 1977), rev'd on other grounds, 589 F.2d 1139 (Ist Cir. 1978).

5. See notes 29-38 infra and accompanying text. 
on the basis of age and sex. In regard to sex, the actuarial tables show that the average woman lives longer than the average man. Insurers therefore have forced women either to make larger contributions to the annuity fund or to receive smaller periodic benefits out of the fund than their male counterparts, thereby permitting benefits to be paid to women over their longer average life expectancy without exhausting the annuity fund. ${ }^{6}$ Of course, the generalization that woinen as a group live longer than men as a group does not always hold true on an individual basis. ${ }^{7}$ Thus, there is a tension between the principles of Title VII and the traditional application of the principles of annuities. Title VII forbids employers from classifying or discriminating against individuals on the basis of sex, while annuities have traditionally required an employer to classify einployees by sex and treat female employees differently $\mathrm{m}$ pension contributions or benefits because of their sex in order to provide an actuarially sound plan.

For fourteen years after the enactment of Title VII, this tension was resolved outside of the courts in favor of traditional annuity principles. In April 1978, however, the Supreine Court of the United States decided City of Los Angeles, Department of Water \& Power v. Manhart, ${ }^{8}$ which lield that Title VII's focus on the imdividual must prevail over any insurance principle of grouping by sex. An einployer-operated pension plan may no longer legally require greater contributions froin female einployees than male employees on the assumption that the females will live longer than their male counterparts. ${ }^{9}$

This Note will discuss the tension between Title VII and applied insurance principles and the Manhart resolution of this tension. In addition, the financial problems that face an einployer attempting to operate a nondiscriminatory pension plan will be examined. The Note will conclude that the Supreme Court's decision in Manhart is a challenge to the actuarial cominumity to devise new standards by which pension plans can be operated on both financially sound and nondiscriminatory bases.

6. See notes 34-35 infra and accompanying text.

7. See, e.g., Henderson v. Oregon, 405 F. Supp. 1271, 1275 n.5 (D. Ore. 1975), in which the court found that only $16 \%$ of women outlive their male counterparts.

8. 435 U.S. 702 (1978). Justice Stevens wrote the opinion of the Court. He was jomed by Justices Powell, Stewart and White. Justice Blackmun concurred in a separate opinion. Justice Marshall concurred and dissented (on the issue of retroactivity) in a separate opinion. Chief Justice Burger wrote a dissenting opinion and was joined by Justice Rehnquist. Justice Brennan did not participate in the Court's decision.

9. Id. 


\section{The Tension Between Title ViI and Annuity Principles}

\section{A. Title VII.}

The main purpose of Title VII of the Civil Rights Act of $1964^{10}$ is "to eliminate . . . discrimination in employment." " The inost overt type of discrimination that Title VII eliminates is a wage differential between men and women performing equal work. However, under certain circumstances, Title VII will permit an einployer to differentiate between his male and female employees with regard to wages or compensation. The Bennett Amendment to Title VII allows such differentiation if it is authorized by the Equal Pay Act. ${ }^{12}$ The Equal Pay Act, im turn, permits a wage differential between members of the opposite sex "where such payment is unade pursuant to . . . (iv) a differential based on any other factor other than sex . . ."13 Enforcement of the provisions of Title VII is thus left to two administrative agencies: the Equal Eunployment Opportunity Cominission (EEOC) is responsible for ensuring comphiance with Title VII and the Wage and Hour Division of the Department of Labor performs a similar role under the Equal Pay Act. ${ }^{14}$

One threshold question concerning the reach of Title VII is whether the statute's coverage extends to einployer-operated pension and annuity plans. When Congress mandated nondiscrimination by employers on the basis of sex with regard to "compensation, terms, conditions, or privileges of employment . . .,"15 did it intend to reach

10. 42 U.S.C. $\$ \$ 2000 \mathrm{e}-2000 \mathrm{e}-15$ (1976).

11. H.R. Rep. No. 914, 88th Cong., 2d Sess. 9, reprinted in [1964] U.S. CodE CoNG. \& AD. NEws 2391, 2401.

12. The Bennett Amendment provides im pertinent part:

It shall not be an unlawful employment practice under this subchapter for an employer to differentiate upon the basis of sex in determining the amount of wages or compensation paid or to be paid to employees of such employer if such differentiation is authorized by the provisions of 206(d) of Title 29.

42 U.S.C. $\$ 2000 \mathrm{e}-2$ (h) (1976). The Equal Pay Act was enacted the year before Title VII.

13. 29 U.S.C. $\$ 206(d)(1)$ (1976). Other circumstances excepted by the Equal Pay Act are "where such payment is made pursuant to (i) a semiority system; (ii) a merit system; (iii) a systcm which measures earnings by quantity or quahty of production ...." Id. For an example of a "factor other than sex" that permitted a compensation differential, see General Electric Co. v. Gilbert, 429 U.S. 125 (1976). The Gilbert case involved an industrial disability plan that did not cover the costs of normal pregnancy. The Supreme Court held that pregnancy was a physical condition that constituted a "factor other than sex" for the purposes of Title VII and the Equal Pay Act, thereby making its noninclusion in the disabihty plan nondiscriminatory. The Gilbert case will be discussed in greater detail in text accompanying notes 65-70 infra.

14. Under current guidelines, the EEOC gives "appropriate consideration" to the interpretations of the Equal Pay Act, but the Commission is not bound by such interpretations. 29 C.F.R. 8 1604.8(b), (c) (1978). The imterplay between the EEOC and the Wage and Hour Division will be examined more fully in the text accompanying notes 56-76 infra.

15. 42 U.S.C. $\& 2000 \mathrm{e}-2(a)(1)(1976)$. 
pension plans? Several United States district courts and circuit courts of appeals have answered this question in the affirmative. ${ }^{16}$ In the cases, at least four propositions are raised in favor of including pension and retirement plans under Title VII. First, Congress foresaw the scope of Title VII as a broad protective shield. ${ }^{17}$ In light of this, one court has determined that it would be wholly inconsistent to exclude pensions fron its coverage. ${ }^{18}$ Second, courts have rehed on the administrative interpretations of the EEOC. ${ }^{19}$ These administrative interpretations explicitly include pension plans under Title VII. ${ }^{20}$ Third, courts have reasoned that Title VII inust include retirement benefits because the language of Title $\mathrm{VII}^{21}$ is similar to that employed in the National Labor Relations Act, ${ }^{22}$ which has been held to include retirement benefits as conditions of eniployinent. ${ }^{23}$ Fourth, courts have held that the legislative history of Title VII does not show a "strong indication of legislative intent"24 that pension plans were to be specifically excluded

16. See, e.g., Peters v. Missouri-Pacific R.R., 483 F.2d 490, 492 n.3 (5th Cir.), cert. denied, 414 U.S. 1002 (1973); Rosen v. Public Serv. Elec. \& Gas Co., 477 F.2d 90, $94-95$ (3d Cir. 1973); Bartmess v. Drewrys U.S.A., Inc., 444 F.2d 1186, 1187-89 (7th Cir.), cert. denied, 404 U.S. 939 (1971); Fitzpatrick v. Bitzer, 390 F. Supp. 278, 286-88 (D. Conn. 1974), affd, 519 F.2d 559 (2d Cir. 1975), rev'd on other grounds, 427 U.S. 445 (1976).

17. During the debates on Title VII, an amendment was offered that would lave limited the scope of the Act to explicit discrimination based solely on sex. "Congress specifically rejected [this] amendment to the Act which would lave so limited the force of the prohibition agamst sex discrimination. Such a limitation, it was felt, would emasculate the Act. See 110 CoNG. Rec. 2728, 13,825 [1964]." Sprogis v. United Air Lines, Inc., 444 F.2d 1194, 1198 n.4 (7th Cir. 1971).

18. "In forbidding employers to discriminate against individuals because of their sex, Congress intended to strike at the entire spectrum of disparate treatment of men and women resulting from sex stereotypes." Sprogis v. United Air Lines, Inc., 444 F.2d 1194, 1198 (7th Cir. 1971).

19. Rosen v. Public Serv. Elec. \& Gas Co., 477 F.2d 90, $94-95$ (3d Cir. 1973); Fitzpatrick v. Bitzer, 390 F. Supp. 278, 286-88 (D. Conn. 1974), aff.d, 519 F.2d 559 (2d Cir. 1975), rev'd on other grounds, 427 U.S. 445 (1976). These administrative interpretations are entitled to great deference in the courts. Griggs v. Duke Power Co., 401 U.S. 424, 433-34 (1971).

20. Until 1972, the guideline relied on by the courts provided that: "A difference in optional or compulsory retirement ages based on sex violates Title VII." 29 C.F.R. $\$ 1604.31$ (a) (1971). In 1972 , the EEOC promulgated new guidelines that inade the inclusion of pension plans under Title VII nore explicit: "(a) 'Fringe Benefits,' as used lerem, includes . . . retirement benefits . . . . (b) It slaall be an unlawful employinent practice for an employer to discriminate between men and wounen with regard to fringe benefits." 29 C.F.R. § 1604.9(a), (b) (1978).

21. "Compensation, terms, conditions or privileges of employment . . " 42 U.S.C. $\S 2000 \mathrm{e}-2(\mathrm{a})(1)(1976)$.

22. "Rates of pay, wages, hours of employinent, or other conditions of employment . . .." 29 U.S.C. \& 159(a) (1976).

23. Inland Steel Co. v. NLRB, 170 F.2d 247 (7th Cir. 1948), cert. denied, 336 U.S. 960 (1949). Under Title VII, one court has held: "We entertain no doubt that Congress intended Title VII to reach retirement plans as conditions of einploynnent, just as such retirement plans are viewed as employment conditions under the National Labor Relations Act." Peters v. Missouri-Pacific R.R., 483 F.2d 490, 492 n.3 (5th Cir.), cert. denied, 414 U.S. 1002 (1973).

24. Bartmess v. Drewrys U.S.A., Inc., 444 F.2d 1186, 1190 (7th Cir.), cert. denied, 404 U.S. 939 (1971). 
from the broad coverage of Title VII, and therefore, the words of the statute $^{25}$ must be read "with their commonly accepted meanings."26 Thus, the lower federal courts have repeatedly and consistently held that Title VII is broad enough im coverage to reach pension and retirement plans. The Supreme Court has never focused on whether Title VII covers pension plans, but it has given cursory treatment to the question of whether the Equal Pay Act permits pension plans to differentiate by $\operatorname{sex}^{27}$

In examining Title VII, the reader cannot mistake the statute's emphasis on the individual: it is unlawful under Title VII "to discriminate agamst any individual ... because of such individual's ... sex ....28 The unmistakable mandate of Title VII is that in employment situations, men and women must be treated as individuals and not treated differently merely because of their gender. Simce Title VII demands individualized treatment of employees and simce Title VII imcludes pension plans, it follows that employers must not differentiate among employees because of their sex $\dot{m}$ the operation of a pension plan. As a practical matter, however, employees traditionally have been treated differently under employer-operated pension plans because of their sex.

\section{B. The Principles and Operations of Annuities. ${ }^{29}$}

1. The Fundamental Principle of Insurance. A fundamental principle of insurance is the spreadimg of risk. This risk-spreading is achieved by grouping together insureds of similar risks. However, grouping by risk does not mean that imsureds of the same risk group will have similar loss experiences. Some members of the group will be better risks than the group average while some will be poorer risks. By attributimg the average risk to each member of the group, the insurer makes the better risks subsidize the poorer risks and spreads the total risk over the group. ${ }^{30}$

25. See note 21 supra.

26. Bartmess v. Drewrys U.S.A., Inc., 444 F.2d 1186, 1190 (7th Cir.), cert. denied, 404 U.S. 939 (1971). See note 77 infra and text accompanying notes 77-82 infra. At least one commentator has suggested a different way of resolving the legislative history dispute in favor of inclusion. The argument is that when Title VII was amended in 1972, Congress could have specifically excluded pension plans, but it did not, thereby vindicating the opinions of the courts. Gold 602. Professor Gold also argues that a fifth reason for inclusion, in addition to the four raised by the courts, is the public policy of protection of pension rights. Id. at 603-04.

27. See tcxt accompanying notes 77-82 infra.

28. 42 U.S.C. $\$ 2000 e-2(a)(1)$ (1976) (emphasis added).

29. In this section, only traditional principles and operations of pensions (i.e., pre-Manhart) are discussed.

30. City of Los Angeles, Dep’t of Water \& Power v. Manhart, 435 U.S. 702, 710 (1978). 
2. Differentiation By Sex. Traditionally, insurers have grouped people on the basis of age ${ }^{31}$ and sex. As noted earlier, the basic assumption underlying the differentiation between inen and women in pension plans-that women live longer than men-is not always valid for individual pensioners. ${ }^{32}$ The life expectancy tables relied on by annuity fund operators reflect only the experience of men and women as groups. As a group, women will live longer than men, and it is group experience that insurers, including annuity funds, rely on in determining the cost of a risk. The pension operator cannot predict when any given individual will die; thus, it is impossible for the operator to calculate the cost of paying such individual a specified amount per month for life, and the operator must rely on actuarial groupings:

It is, of course, true that actuarial tables of some sort should be used, for longevity cannot be determined for any particular individual. This rehance means that statistically average characteristics will be attributed to individual meinbers of a described class; even if such tables accurately generalize about a group whose members are in soine way similarly situated, they are necessarily inaccurate as to particular members. ${ }^{33}$

The insurance justification for this differentiation between the sexes is the fact that the life expectancy of women is greater than that of men at all ages, ${ }^{34}$ which means that periodic benefits must be paid to women for a longer time span than to men. On this basis, annuities either charge woinen more than men for an annuity or give women smaller periodic benefits than men in order that the fund will not be depleted until the last annuitant of the fund has died. ${ }^{35}$

Insurance deals with transference of risk. Since no individual can ever know with certainty the risk he represents, he joins a larger group and, through the operation of the laws of probability and large numbers, protects himself from his uncertainty. This transference is at the core of insurance principles.

Note, Sex Discrimination and Sex-Based Mortality Tables, 53 B.U.L. REv. 624, 653-54 (1973). See generally J. MaGee \& D. Bickelhaupt, General Insurance 3-50 (7th ed. 1964); R. Mehr \& E. Cammack, Principles of Insurance 3-47 (5th ed. 1972).

31. Grouping by age is discussed in note 104 infra.

32. There is evidence that the overlap of death ages of men and women is as high as $84 \%$. Henderson v. Oregon, 405 F. Supp. 1271, 1275 n.5 (D. Ore. 1975); King, Men, Women, and Life Annuities, 43 J. Risk \& INs. 553, 556-57 (1976) (quoting Professor Barbara Bergmann of Committee $\mathrm{W}$ of the American Association of University Professors).

33. Bernstein \& Williams, Title VII and the Problem of Sex Classifications in Pension Programs, 74 Colum. L. Rev. 1203, 1208 (1974).

34. Current life expectancy tables show that the life expectancy of a 65 year-old male is 17 years while that of his female counterpart is 21 years. Edwards, A Benefit Manager's Guide to Sex, 42 J. RIsK \& INS. 189, 193 (1975).

35. This, of course, is the cardinal principle of annuities. Sce text accompanying note 4 supra. The Enuployee Retirement Income Security Act of 1974, 29 U.S.C. \$\$ 1081-1086 (1976), requires that pension plans be actuarially sound but is of no help in determining what is an actuarially sound treatinent of sex. 
The principal business reason for pension operators to differentiate on the basis of sex is that men comprise a larger share of the annuity market than wounen, and sex-segregated actuarial tables keep premiuns lower for men than if the two sexes were grouped together. ${ }^{36}$ Thus, pension operators classify by sex to remain competitive in a predominantly inale market. Other business justifications for classification by sex include the following: (1) the classification is easy to determine and apply; ${ }^{37}(2)$ it yields statistically valid predictions; and (3) it yields relatively broad groupings that in turn allow for the spreading of risk, which is at the heart of insurance philosophy. ${ }^{38}$

3. Types of Pension Plans. A pension plan inay be of two types: a defined benefit plan or a defined contribution plan. ${ }^{39}$ In a defined benefit plan, the plan operator agrees to pay its annuitants a set annount each period, usually monthly, and then sets contributions at a level to meet the predetermined benefit obligations. In a defined contribution plan, the reverse is true. The contributions to the pension plan are predetermined. Benefits, rather than being stated, are a function of the anount of contributions and investment performance. ${ }^{40}$ The distinction between the two types of plans is that under a defined contribution plan men and women inake cqual contributions, but inen receive larger periodic benefits; while under a defined benefit plan, woinen inake higher contributions than inen, but periodic benefits are the saine for both sexes. ${ }^{41}$ Regardless of which type of plan is used, the cost is greater for woinen, either because they pay more into the fund than men in order to receive periodic benefits equal to those of the men or because they are receiving a sinaller periodic benefit than inen after

36. Gold 623 n. 110 .

37. A person's sex is easily determinable, unlike other possible classifications, such as the ages at which one's parents died. Sexual classification is also easy to apply because sex is normally iminutable, unlike the traits of sinoking, drinking and obesity.

38. See generally Gold; Halperin \& Gross 245-50; Note, supra note 30, at 625-28.

39. A defined benefit plan is also known as a forınula benefit plan. Similarly, a defined contribution plan can be called a inoney purchase plan.

40. See generally Edwards, supra note 34, at 193; Halperin \& Gross 236-38. Of course, the contribution rate is frequently determined by some set of benefits goal, making it difficult to distinguish the two types of plans.

41. Halperin \& Gross 238. To illustrate, assume a 65 year-old man and a 65 year-old woinan both began paying into an annuity plan at age 60 and both will hive to age 70 . Under a defined contribution plan, both will have paid into the fund $\$ 100$ per month, but the man will receive benefits of $\$ 100$ per month while the woman will receive $\$ 85$. Under a defined benefit plan, the nan will have paid into the fund $\$ 100$ per month while the woman will have made corresponding payments of $\$ 115$ per month; both the man and the woinan will receive benefits of $\$ 100$ per month. These figures are hypothetical, and an actual fund operator will determine his figures by use of sex segregated actuarial tables. 
having made contributions equal to those made by men.

The fundamental principles of insurance are grouping of risks and spreading of risks. The basic concern of Title VII is that employers not discriminate against employees because of an individual employee's sex. Because pension operators have traditionally differentiated between inen and woinen, there has been a conflict between the application of the insurance principle of grouping and the Title VII principle of fairness to individuals. This conflict was presented for resolution to the Supreme Court in City of Los Angeles, Department of Water \& Power v. Manhart. ${ }^{42}$

\section{The Manhart CASE}

\section{A. Facts and Holding.}

The Los Angeles Department of Water and Power operated a retirement, disability and deatlı benefits program for its employees. The retirement benefits part of the program was administered as a defined benefit plan with men and women of the same age, seniority and salary receiving equal periodic benefits. ${ }^{43}$ These benefits were funded by employee and employer contributions ${ }^{44}$ and the investment earnings on such contributions. In administering the defined benefit plan, the Departinent followed standard imsurance procedure and utilized separate life expectancy tables for its male and female employees to determine the level of contributions. To account for the greater life expectancy of feniales as a group and the resulting higher cost of pensions for the feinale einployee group, contributions by female employees were almost fifteen percent higher than for similarly situated male employees. ${ }^{45}$ Because employee contributions were deducted from pay cliecks, fernale einployees earning the same base salary as male employees took home less pay than their male counterparts.

A group of past and present female employees brought a class action suit against the Department on belralf of women whom it employed or fornerly employed. The complaint alleged that by requiring higher contributions from female employees than from male employees the Department was discriminating on the basis of sex agamst each feinale enuployee with respect to her "compensation, teruns, conditions, or privileges of employnent" 46 in violation of Title VII. The female em-

42. 435 U.S. 702 (1978).

43. See notes $39-41$ supra and accompanying text.

44. Employer contributions equaled $110 \%$ of employee contributions. 435 U.S. at 705 n.4.

45. See notes 34-35 supra and accompanying text.

46. 42 U.S.C. $\$ 2000 \mathrm{e}-2$ (a)(1) (1976). See note 3 supra. 
ployees sought an injunction against the differential in contributions and restitution of past excess contributions. ${ }^{47}$

The Manhart case thus squarely presented the Supreme Court with a clash between the principles of Title VII and the traditional operations of the insurance imdustry. The Supreme Court resolved this clash of competing principles in favor of Title VII, holding that the Departinent could not assess female employees at a higher contribution rate than its male employees: ${ }^{48}$

[Title VII's] focus on the individual is unambiguous. It precludes treatment of individuals as simply components of a racial, rehigious, sexual, or national class. If height is required for a job, a tall woman may not be refused employment merely because, on the average, women are too short. Even a true generalization about a class is an msufficient reason for disqualifying an individual to whoin the gen-

47. Although the Department's retirement benefits program had been in operation for several years, it only became subject to Title VII on March 24, 1972, the effective date of amendments to Title VII. The amendments redefined "employer" to imclude state and local governments. 42 U.S.C. $\$ 2000 \mathrm{e}(\mathrm{b})$ (1976). The amendments were made in Pub. L. No. 92-261, 88 Stat. 103 (1972). The Cahfornia legislature, after the initial complaint in Manhart had been filed, enacted a law requirmg governmental units to equalize pension contributions as of January 1, 1975. CAL. Gov'T CoDe $\S 7500$ (West Supp. 1978). The Department complied with this law by lowering female contributions to the level of male contributions and by increasing its contributions on behalf of its female employees. Telephone interview with David J. Ohphant, Deputy City Attomey, City of Los Angeles, Cahifornia (Oct. 10, 1978) (Mr. Oliphant represented the Department before the Circuit Court of Appeals and the Supreme Court). Consequently, by the time the Manhart case came before the Supreme Court, only the pension contributions for the years 1972-1975 were contested by the parties. The injunction sought by the female employees was thus mooted, but the question of a substantial violation of Title VII during 1972-1975 was properly before the Court on the issue of the propriety of retroactive relief.

The district court in Manhart held that the contribution differential violated Title VII and ordered all excess contributions refunded. 387 F. Supp. 980 (C.D. Cal. 1975). The Ninth Circuit affirmed. 553 F.2d 581 (1976).

48. However, the Supreme Court did not grant the female employees' request for restitution of the excess contributions made between March 24, 1972 and December 31, 1975. While the Court acknowledged the doctrine of Albemarle Paper Co. v. Moody, 422 U.S. 405 (1975), which creatcs a presumption in favor of retroactive relief, it nevertheless held that the presumption was overcome in this case for the following reasons: (1) "Pension administrators could reasonably have thought it unfair-or even illegal-to make male employees shoulder more than than their 'actuarial share' of the pension burden," 435 U.S. at 720; (2) "[t]here is no reason to believe that the threat of a backpay award is needed to cause other administrators to amend their practices to conform to this decision," Id. at 720-21; and (3) there were potential adverse effects that retroactive relief could have on the hquidity of pension funds (which amounted to over $\$ 400$ billion at the end of 1977) and on the general econony, id. at 721-23. Justice Marshall, who concurred in the rest of the Court's judgment, dissented on the issue of retroactive rehef. Concerning the first point raised by the Court, Marslıall pointed out that the EEOC guidelines, see notes 56-64 infra and accompanying text, have prohibited unequal contributions simce 1972 and that the Department should have been put on notice by the guidelines that it was in violation of Title VII. Marshall ignored the Court's second argument. Regarding the third poimt, the dissent noted that it was not shown that the amount of backpay involved in this case would lave a devastating cffect on the plan. Id. at $728-33$. 
eralization does not apply.

That proposition is of critical importance in this case because there is no assurance that any individual woinan working for the Department will actually fit the generalization on which the Departinent's policy is based. Many of those individuals will not live as long as the avcrage man. While they were working, those individuals received small paychecks because of their sex, but they will receive no compensating advantage when they retire.

It is true, of course, that while contributions are being collected from the employees, the Departmcnt cannot know which mdividuals will predecease the average woman. Therefore, unless women as a class are assessed an extra charge, they will be subsidized, to some extent, by the class of male employees. ${ }^{49}$

Although one commentator has said that "[t]he outcome of the case should not have been startling to anyone . . . except for the sheer ubiquitousness of actuarial habits persisting after enactment of the Civil Rights Act of 1964,"50 the defendants in Manhart sought to defend the higher contributions assessed to the female employees with four arguments. First, the Department argued that the guidelines of the Wage and Hour Division of the Department of Labor took precedence over the guidelines of the EEOC, and that the Wage and Hour Division guidelines authorized a differential in contributions. ${ }^{51}$ Second, the Department contended that the legislative histories of Title VII and the Equal Pay Act made it clear that pension plans and other employee benefit plans were excluded from the coverage of Title VII. ${ }^{52}$ Third, the Department argued that the differentiation was based on longevity, not on sex, thereby bringing the alleged discrimination within the "factor other than sex" exclusion to Title VII of the Bennett Amendment. ${ }^{53}$ The fourth defense raised by the Departinent was that equal contribution levels for inale and feinale employees would be unfair to the group of male employees that would be forced to subsidize the group of female employees. In other words, the higher contributions for females did not constitute discrimination because the higher amounts were offset by the higher value of pension benefits provided to

49. 435 U.S. at 708-09.

50. Van Alstyne, Equality for Individuals or Equality for Groups: Implications of the Supreme Court Decision in the Manhart Case, 64 AM. A.U. Professors Bull. 150, 151 (1978).

51. Opening Brief for Petitioner at 10-23, 46-49, City of Los Angeles, Dep't of Water \& Power v. Manhart, 435 U.S. 702 (1978). For the provisions and an analysis of the various guidelines, see notes 56-76 infra and accompanying text. All subsequent citations to the briefs of the respective parties are to the briefs filed in the Manhart case in the Supreme Court unless otherwise indicated.

52. Opening Brief for Petitioner at 10-23, 46-49.

53. Opening Brief for Petitioner at 46-49; Reply Brief for Petitioner at 14-16. 
the female employees due to that group's greater average longevity. ${ }^{54}$ In making its first three arguments, the Department rehed on the Supreme Court's decision in General Electric Co. v. Gilbert, ${ }^{55}$ in which the Court upheld the exclusion from an employer disability plan of the costs resulting from pregnancy and childbirth. The next section of this Note examines the defenses raised by the Department and demonstrates that the Supreme Court properly rejected them.

\section{B. Analysis of the Manhart Opinion.}

1. Guidelines of the EEOC and the Wage and Hour Division. The principal government agency responsible for the enforceinent of Title VII is the EEOC. ${ }^{56}$ In Title VII actions, the defendant is allowed to raise as a defense the fact that the alleged discriminatory employment practice is authorized by the provisions of the Equal Pay Act. ${ }^{57}$ The principal enforcement agency under the Equal Pay Act is the Wage and Hour Division of the Department of Labor. ${ }^{58}$ Thus, in any action involving Title VII, attention must be given to the interplay of the guidelines promulgated by the EEOC and the Wage and Hour Division. ${ }^{59}$

54. Reply Brief for Petitioner at 16-23.

55. 429 U.S. 125 (1976).

56. 42 U.S.C. $\$ \$ 2000 \mathrm{e}-4,5,6,8,9$ (1976).

57. See notes 12-13 supra.

58. See note 14 supra.

59. It is important to note that the "guidelines" issued by these agencies are not "regulations." Albemarle Paper Co. v. Moody, 422 U.S. 405, 43 I (1975). A regulation promulgated under statutory authority must be given the same effect as a pronouncement of Congress. A guideline, however, is accorded a different treatment by the courts:

We consider that the rulings, imterpretations and opimions of the Admimistrator under this Act, while not controllimg upon the courts by reason of their authority, do constitute a body of experience and informed judgment to which courts and litigants may properly resort for guidance. The weight of such a judgment in a particular case will depend upon the thoroughness evident in its consideration, the validity of its reasoning, its consistency with earlier and later pronouncements, and all those factors which give it power to persuade if lacking power to control.

Skidmore v. Swift \& Co., 323 U.S. 134, 140 (1944); accord, Griggs v. Duke Power Co., 401 U.S. 424, 433-34 (1971).

In addition to the EEOC and the Wage and Hour Division, two other federal agencies have authority to issue guidelines concerning sex discrimmation in employment. The Office of Federal Contract Compliance Programs (OFCCP) has responsibility under Exec. Order No. 11,246, as amended by Exec. Order No. 11,375, 3 C.F.R. $\$ 406$ (1969), to pohice sex discrimination by federal contractors. Under Title IX of the Educational Amendments Act of 1972, Pub. L. No. 92-318, 86 Stat. 373, the Department of Health, Education and Welfare is given the task of ensuring that educational institutions receiving federal funds do not discriminate against their employees because of the employees' sex. Prior to Manhart, the guidelines of the OFCCP, 41 C.F.R. $\$ 60$ 20.3(c) (1977) and the guidelines of HEW, 39 Fed. Reg. 22,237 (1974) (to be codified in 45 C.F.R. $\$ 86.46(\mathrm{~b})(2)$ ), followed the Wage and Hour Division, thus making them secondary for the purposes of this discussion. But $f f$. the proposed amendments to the guidelines of the OFCCP at 43 Fed. Reg. 38,057 (1978) (the OFCCP withdrew its support of the old Wage and Hour Division 
Prior to 1972, the EEOC bound itself to the guidelines of the Wage and Hour Division under the Equal Pay Act. ${ }^{60}$ The Wage and Hour Division approved of traditional insurance practices under both defined contribution and defined benefit plans. The Division's guidelines permitted an employer to comply with the Equal Pay Act, and thus Title VII, either by making equal contributions for einployees of both sexes or by providing equal benefits to both sexes. ${ }^{61}$ The Wage and Hour Division guidelines formulated no rule regarding a differential in the amount of employee contributions. ${ }^{62}$ In 1972, however, the EEOC promulgated new guidelines. In these guidelines, the EEOC said that it would no longer consider as binding in Title VII actions the interpretations of the Equal Pay Act by the Wage and Hour Division. ${ }^{63}$ The Commission then announced its own rule on pension and retirement benefit plans: benefits to inembers of each sex must be equal without regard to whether contributions are equal, and it is no defense to a charge of sex discrimination under Title VII that it costs the employer inore to provide the same benefits to ineinbers of one sex than to the

guideline in favor of the post-Manhart proposed Wage and Hour Division guideline. See text accompanying note 74 infra).

60. The interpretative bulletin of the EEOC provided as follows:

(a) Title VII requires that its provisions be harmonized with the Equal Pay Act (section 6(d) of the Fair Labor Standards Act of 1938, 29 U.S.C. \$ 206(d)) in order to avoid conflicting interpretations or requirements with respect to situations to which both statutes are applicable. Accordingly, the Commission interprets section 703(h) [The Bennett Amendment] to mean that the standards of 'equal pay for equal work' set forth in the Equal Pay Act for determining what is unlawful discrimination in compensatiou are applicable to Title VII. ... .

(b) Accordingly, the Commission will make applicable to equal pay complaints filed under Title VII the relevant imterpretations of the Administrator, Wage and Hour Division, Department of Labor. . . . Relevant opimions of the Administrator interpreting 'the equal pay for equal work standard' will also be adopted by the Commissiou.

29 C.F.R. § 1604.7(a), (b) (1968).

61. The guideline provides:

Contributions to employee benefit plans. If employer contributions to a plan providing insurance or similar benefits to employees are equal for both men and women, no wage differential prohibited by the equal pay provisions will result from such paynents, even though the benefits which accrue to the einployees in question are greater for one sex than for the other. The mere fact that the employer may make unequal coutributions for employees of opposite sexes in such a situation will not, however, be considered to indicate that the employer's payments are in violation of section 6(d), if the resulting benefits are equal for such employees.

29 C.F.R. $\S 800.116$ (d) (1978). This guideline is often referred to as the "either-or" rule.

62. The Departunent of Labor stressed this very point in an amicus brief in the Manhart case in the Ninth Circuit. Amicus Brief for Secretary of Labor, Umited States Department of Labor at 4, 6, Manhart v. City of Los Angeles, Dep't of Water \& Power, 553 F.2d 581 (9th Cir. 1976).

63. The guideline provides:

(b) By virtue of section 703(h), a defense based on the Equal Pay Act may be raised in a proceeding under Title VII.

(c) Where such a defense is raised the Commission will give appropriate consideration to the interpretations of the Administrator, Wage and Hour Division, Department of Labor, but will not be bound thereby.

29 C.F.R. \& 1604.8(b), (c) (1978). 
other ${ }^{64}$ Thus, as of 1972 , the Wage and Hour Division permitted either equal employer contributions or equal benefits to satisfy the Equal Pay Act, while the EEOC demanded equal benefits regardless of the equality or inequality of employer contributions. Then, in 1976, the Supreme Court decided General Electric Co. v. Gilbert. ${ }^{65}$ In Gilbert, female employees filed a Title VII sex discrimination charge against their employer on the basis of the employer's practice of excluding from its employee nonoccupational disability plan disabilities arising from pregnancy. The Court decided the case in favor of the employer. To reach this decision, the Court was forced to deal with contradictory guidelines of the EEOC and the Wage and Hour Division. The EEOC guideline expressly stated that disabilities caused by pregnancy were to be included as temporary disabilities under temporary disability plans. ${ }^{66}$ On the other side was the "either-or" rule of the Wage and Hour Division. ${ }^{67}$ The Supreme Court found, incident to its decision in Gilbert, that the "either-or" rule of the Wage and Hour Division was the correct interpretation of the law under Title VII. ${ }^{68}$ In so finding, the Court disposed of the EEOC guideline by applying the thoroughness, vahitity and consistency tests of Skidmore v. Swift \& Co. ${ }^{69}$ The Court found that the EEOC guideline was inconsistent with earher pronounceinents of the agency and that when the EEOC issued the new guideline, it did so without relying on any new source of legislative history. ${ }^{70}$

Two years later, when presented with the Manhart case, the Supreme Court took a dim view of the Wage and Hour Division's "either-or" guideline ${ }^{71}$ that had been favorably viewed in Gilbert. The

\section{The guideline provides:}

(e) It shall not be a defense under title VIII [sic] to a charge of sex discrimination in benefits that the cost of such benefits is greater with respect to one sex than the other.

(f) It shall be an unlawful employment practice for an employer to have a pension or retirement plan... which differentiates in benefits on the basis of sex....

29 C.F.R. \& 1604.9 (e), (f) (1978).

65. 429 U.S. 125 (1976).

66. The guideline provides:

Disabilities caused or contributed to by pregnancy, miscarriage, abortion, childbirth, and recovery therefrom are, for all job-related purposes, temporary disabilities and should be treated as such under any health or temporary disability insurance or sick leave plan available in connection with employment. . . . [Benefits] shall be applied to disabihity due to pregnancy or childbirth on the same terms and conditions as they are applied to other temporary disabilities.

29 C.F.R. § 1604.10(b) (1978).

67. See note 61 supra.

68. 429 U.S. at 145.

69. 323 U.S. at 140 . See note 59 supra.

70. 429 U.S. at 142,145 (1976).

71. 435 U.S. at 714 n.26 (describing the "either-or" guideline, and reciting the reasons for establishing such a guideline as perceived by the Administrator of the Wage and Hour Division). 
Court disavowed the "either-or" guideline in favor of another Wage and Hour Division guideline that provided that a wage differential based on differences in the average costs of einploying men and women violated the Equal Pay Act. ${ }^{72}$ As applied to the facts of Manhart, this decision meant that the differential in take-home pay due to the differential im pension contributions based on the higher average cost of pension for female employees could not qualify for the "factor other than sex" exception to the Equal Pay Act.

In rejecting the "either-or" guideline, the Court utilized the Skidmore doctrine, the very doctrine that it had relied upon to uphold the "either-or" rule in Gilbert. However, the Court was not required to reject the "either-or" rule in order to approve of the "differential wages-differential costs" guideline: the former covers only employer contributions while the latter covers only employee contributions, and only employee contributions were involved in Manhart. Given the fact that the "either-or" rule expressly permits employer contributions to be a function of sex if the benefits themselves are equal, the Court apparently reasoned that the rule would permit employee contributions to vary with sex if the benefits are equal. By so rejecting the "either-or" guideline, the Supreme Court necessarily overruled the Gilbert case to the extent that it depended on the Wage and Hour Division's adminis-

72. The guideline provides:

A wage differential based on claimed differences between the average cost of employing the employer's women workers as a group and the average cost of employing the men workers as a group does not qualify as a differential based on any "factor other than sex," and would result in a violation of the equal pay provisions, if the equal pay standard otherwise applies. To group employees solely on the basis of sex for purposes of comparison of costs necessarily rests on the assumption that the sex factor alone may justify the wage differential - an assumption plainly contrary to the terms and purposes of the Equal Pay Act. Wage differentials so based would serve only to perpetuate and promote the very discrimimation at which the Act is directed, because in any grouping by sex of the employees to which the cost data relates, the group cost experience is necessarily assessed against an individual of one sex without regard to whether it costs an employer inore or less to employ such individual than a particular individual of the opposite sex under similar working conditions im jobs requiring equal skill, effort, and responsibility.

29 C.F.R. $§ 800.151$ (1978).

The Court saw Manhart as presenting only a conflict between the two Wage and Hour Division guidelines, whereas Gilbert posed a conflict between a Wage and Hour Division guideline and an EEOC guideline. Arguably, the Court could have found a conflict between the guidelines of the two agencies. The EEOC guideline, 29 C.F.R. $\$ 1604.9$ (e) (1978), says that an employer cannot provide unequal benefits to male and female employees simply because it would cost it more with respect to one sex than the other. See note 64 supra for the text of this section. The Court could have read the EEOC guideline as implicitly forbidding an employer from passing on the extra cost of pension benefits to the class of female einployees because the guideline would have no teeth without such an implicit prohibition. Operators of the outlawed unequal benefits plans could comply with the guideline simply by providing for unequal contributions. Had the Court been willing to so read the EEOC guideline, it could have had an additional conflict with the "either-or" rule of the Wage and Hour Division. 


\section{trative interpretation of the Equal Pay Act. ${ }^{73}$}

Since Manhart was decided, the Wage and Hour Division has promulgated proposed revisions to certain of its guidelines. ${ }^{74}$ Under the proposed guidelines, the Division acquiesces in the Manhart decision and replaces the "either-or" rule with the rule that both employee contributions and benefits must be equal. ${ }^{75}$ Any differential in the cost of einploying the sexes must therefore be absorbed by the einployer. The conflicting EEOC and Wage and Hour Division guidelines prior to Manhart led two commentators to conclude that "to speak of a 'settled' administrative interpretation of the laws does not accord with reality." ing nodifications in the Wage and Hour Division guidelines, however, it now appears that a settled adininistrative interpretation of Title VII and the Equal Pay Act is becoming a reality.

2. Legislative History of Title VII. One of the grounds for the holding in Gilbert was that the effect of the Bennett Amendment was to remove gender-based distinctions in the operation of pension plans from the coverage of Title VII. ${ }^{77}$ The Court's basis for this conclusion

73. An interesting case for the purposes of the present discussion is EEOC v. Colby College, 439 F. Supp. 631 (D. Me. 1977), rev'd, 589 F.2d 1139 (lst Cir. 1978). The district court opinion was handed down after the Supreme Court decided Gilbert but before it decided Manhart, although Manhart had been decided by the Ninth Circuit. In the Colby College case, both einployer and employee contributions were equal between the sexes, but females received sinaller periodic benefits than males (a defined benefit plan). The district court refused to find a violation of Title VII relying on the Supreme Court's approval of the "either-or" guideline in Gilbert. The Colby College court attempted to distinguish Manhart from Gilbert and the case before it on the grounds that Manhart did not involve a conflict between an EEOC guideline and a Wage and Hour Division guideline, while the other two cases did involve such a conflict; furthermore Gilbert required the Wage and Hour Division guideline to prevail. Unsurprisingly, the First Circuit reversed the trial court relying on the Supreme Court's disavowal of the "either-or" guideline. 589 F.2d 1139 (Ist Cir. 1978).

74. 43 Fed. Reg. 38,029 (1978) (to be codified in 29 C.F.R. $\$ 800$ ).

75. The proposed guideline provides:

(d) Employee benefits. Enployee benefits are "wages" within the ineaning of the [Equal Pay A]ct. A differential in benefits based upon differences between the cost to the employer of providing benefits to women as a group and the cost of providing benefits to men as a group does not qualify as a differential based on a "factor other than sex" within the meaning of section 6(d)(1)(iv) of the act. Such a differential therefore violates the equal pay requirements of the act. Similarly, the act is violated if einployees of one sex are required to make greater contributions froin their wages than are employees of the opposite sex in order to receive equal benefits. Los Angeles Dep't of Water \& Power v. Manhart . . . . See also $\S 800.151$ of this chapter.

43 Fed. Reg. 38,029, 38,031-32 (1978). The fact that this guideline requires equal employee contributions supports the argument unade in note 72 supra that the EEOC guidelines imply a requirement of equal employee contributions.

76. Bernstein \& Williams, supra note 33, at 1209.

77. 429 U.S. at 143-46. Gilbert was the first time the Supreme Court considered whether any of the exceptions to Title VII excluded sex discrimination from coverage in pension plans. Al- 
was the Randolph-Humphrey exchange in the Senate during which Senator Huinphrey stated that differences in treatment of the sexes in industrial benefit plans could continue under Title VII. ${ }^{78}$ The Court commented: "[T]he quoted language of Senator Humphrey, the floor inanager of Title VII in the Senate, . . . support[s] what seems to us to be the 'plain meaning' of the language used by Congress when it enacted $\S 703(a)(1)$ [of Title VII]." Senator Humphrey's comment was offered as an interpretation of the Bennett Amendment as it incorporated the Equal Pay Act. The Court was wrong to use this piece of legislative history to interpret the basic antidiscrimination provision of Title VII.

Two years after Gilbert, the Court in Manhart recognized that Senator Humphrey's stateinent actually referred to the Equal Pay Act and not to Title VII. ${ }^{80}$ It concluded that "Senator Humphrey's isolated comment on the Senate fioor cannot change the effect of the plam [antidiscriminatory] language of the statute itself." ${ }^{81}$ Although the Court did not expressly overrule Gilbert on this point, it cannot be doubted that Manhart does in fact overrule the interpretation given to the legislative history in Gilbert. ${ }^{82}$

though the district court in Fitzpatrick v. Bitzer, 390 F. Supp. 278 (D. Conn. 1974), decided that Title VII did prohibit differences in treatment of the sexes in pension plans, the Supreme Court did not consider the question when the Fitzpatrick case came before it. 427 U.S. 445 (1976).

78. Mr. Randolph: Mr. President, I wish to ask of the Senator from Minnesota [Mr. Humphrey], who is the effective manager of the pending bill, a clarifymg question on the provisions of Title VII. I have in mind that the social security system, in certain respects, treats men and women differently. For example, widow's benefits are paid automatically; but a widower qualifies only if he is disabled or if he was actually supported by his deceased wife. Also, the wife of a retired employee entitled to social security receives an additional old age benefit: but the husband of such an einployee does not. These differences in treatment as I recall, are of long standing.

Am I correct, I ask the Senator from Minnesota, in assuming that similar differences of treatment in industrial benefit plans, including earlier retirement options for women, unay continue in operation under this bill, if it becomes law?

MR. HUMPHREY: Yes. That point was made unmistakably clear earlier today by the adoption of the Bennett amendment, so there can be no doubt about it.

110 CONG. Rec. 13,663-64 (1964).

Apparently, Senator Humphrey behieved that the Bennett Amendment contained an exemption froun Title VII for gender-based distinctions in retirement plans, but no explicit language of that provision, 42 U.S.C. $\$ 2000$ e-2(h) (1976), contams such an exception. For a discussion of why the "factor other than sex" exception of the Equal Pay Act as incorporated into Title VII by the Bennett Amendment is inapplicable, see notes 85 \& 92 infra and text accompanymg notes 83-92 infra.

79. 429 U.S. at 145.

80. 435 U.S. at 714.

81. Id.

82. Telephone interview with David J. Oliphant, Deputy City Attomey, City of Los Angeles, California (Oct. 10, 1978) (Mr. Oliphant represented the Department in Manhart at the appellate level). 
3. Longevity as a "Factor Other Than Sex." The third reason the Supreme Court in Gilbert allowed the employer to exclude from a disability plan the costs incurred due to pregnancy was that pregnancy is a factor other than sex that renders any wage or benefits differential nondiscriminatory ${ }^{83}$ The reasoning underlying this holding was that Title VII, which incorporates the Equal Pay Act by virtue of the Bennett Amendment, permits a wage differential between the sexes "where such payment is made pursuant to ... a differential based on any other factor other than sex." 84 The Court pointed out in Gilbert that the distinction was not drawn along sexual lines, for the class of nonpregnant persons includes women as well as men. Pregnancy, thus, is a physical condition, not a gender-based trait, and its costs could be lawfully excluded from a disability plan, absent a showing of actual discriminatory intent. ${ }^{85}$

In Manhart, the Department argued that the contributions differ-

\begin{abstract}
83. 429 U.S. at $133-40$.
84. Id. at 143 n.21.

85. The Cahfornia insurance program does not exclude anyone from benefit eligibility because of gender but merely removes one pliysical condition-pregnancy-from the list of compensable disabilities. While it is true that only women can become prcgnant, it does not follow that every legislative classification concerning pregnancy is a sex-based classification .... Normal pregnancy is an objectively identifiable physical condition with unique characteristics. Absent a showing that distinctions involving pregnancy are mere pretexts designed to effect an invidious discrimination against the members of one sex or the other, lawmakers are constitutionally free to mclude or exclude pregnancy from the coverage of legislation sucls as this on any reasonable basis, just as with respect to any other physical condition.

The lack of identity between the excluded disability and gender as such nnder this insurance program becomcs clear upon the most cursory analysis. The program divides potential recipients into two groups-pregnant women and nonpregnant persons. While the first group is exclusively female, the second includes members of both sexes.
\end{abstract}

429 U.S. at 134-35 (quoting Geduldig v. Aiello, 417 U.S. 484, 496-97 n.20 (1974)). Geduldig was a challenge factually similar to Gilbert, but based upon the cqual protection clause of the fourteenth amendment as opposed to Title VII.

The Court in Gilbert did not expressly incorporate the "factor other than sex" Inle of the Equal Pay Act into its reasoning, but it is clear by implication from the quote above that the Court viewed pregnancy as a plysical condition, and thus a factor other than sex. The Court did not bring the Equal Pay Act into its analysis because there was no wage differential resulting from the exclusion of benefits due to pregnancy, 429 U.S. at 137-40, such differential being required to invoke the Equal Pay Act. In making this finding, the Court looked at the benefits received by fermale employees and male employees, and concludcd that "there is no proof that the package is in fact worth more to men than to women." Id. at 138. Tlus, in the words of the Court, it measured benefits to women and men not on the basis of individual employees, but on the basis of "the aggregate risk protcction derived by that group or class from the program." Id. (quoting the Court in Geduldig, 417 U.S. at 496). Compare this ineasurement scheme with the standard set by the Court two years later in Manhart: "[T]he basic policy of the statute [Title VII] requires that we focus on fairness to individuals rather than fairness to classes." 435 U.S. at 709. Thus, in Gilbert, the Court utilized actuarial data on the group experiences of men and women whicls it had held to be impermissible in Manhart. In Gilbert, the Court should have accepted, for the sake of argument, that a differential on an individual basis existed, and then applied the Equal Pay Act to find that pregnancy was a "factor other than sex" that precluded a finding of discrimination. 
ential was based on longevity, a "factor other than sex."86 The Supreme Court directly answered this argument in the Manhart opinion:

It is plain . . . that any individual's bife expectancy is based on a nuunber of factors, of which sex is only one. The record contains no evidence that any factor other than the employee's sex was taken into account in calculating the $14.84 \%$ differential between the respective contributions by men and women. We agree with Judge Duniway's observation [in the Ninth Circuit's opinion in Manhart] that one cannot "say that an actuarial distinction based entirely on scx is "based on any other factor other than sex.' Sex is exactly what it is based on." ${ }^{\text {87 }}$

The Court went on to say that "[o]n its face, this plan [Manhart] discriminates on the basis of sex whereas the General Electric plan discriminated on the basis of a special physical disability." 88 Thus, pregnancy is a "factor other than sex," but longevity, when based entirely on sex, is not. The key to distinguishing Gilbert and Manhart on this point is that the class of nonpregnant persons in Gilbert is coinposed of ineinbers of both sexes while the group attributed with greater longevity in Manhart is exclusively female, and therefore subject to the coverage of Title VII. ${ }^{89}$ Although Manhart implicitly overruled the Gilbert holding as to administrative guidelines ${ }^{90}$ and legislative history, ${ }^{91}$ it left untouched the determination of Gilbert that pregnancy is a "factor other than sex." 92

86. Opening Brief for Petitioner, 46-49; Reply Brief for Petitioner, 14-16.

87. 435 U.S. at 712-13 (emphasis added).

88. Id. at 715 .

89. Id.

90. See text accompanying note 73 supra.

91. See text accompanying note 82 supra.

92. The Court in Manhart did not expressly overrule Gilbert or any part thereof. In a separate opinion, Mr. Justice Blackmun chastised the Court for this. Blackmun, however, did not concern himself with the administrative interpretatious and legislative history prongs. He would have overruled Gilbert in its entirety due to the third proug:

The Court's distinction between the present case and General Electric-that the permitted classes there were "pregnant women and nonpregnant persons," both female and male, . . . seems to me to be just too easy. It is probably the only distinction that can be drawn. For me, it does not serve to distinguish the case on any principled basis. I therefore inust conclude that today's decision cuts back on General Electric, and inferentially on Geduldig, the reasoning of which was adopted there, . . . and, indeed makes the recognition of those cases as continumg precedent soinewhat questionable. I do not say that is necessarily bad. If that is what Congress has chosen to do by Title VII-as the Court today with such assurance asserts-so be it. I feel, however, that we should meet the posture of the earlier cases head on and not by their rationalization that seeks to distimguish but fails in its quest.

435 U.S. at 725.

While the Supreme Court allowed Gilbert to survive on its third prong, the Congress dealt Gilbert its death blow. After Manhart, an amendment to Title VII was enacted denying pregnancy the status of a "factor other than sex." The statute provides in pertinent part:

The terms "because of sex" or "on the basis of sex" include, but are not limited to, 
4. Does the Equal Employee Contributions-Equal Benefits Rule of Manhart Discriminate Against Men? In Manhart, the Department argued that if the group of female employees both contributed to the pension fund and received periodic benefits on a basis equal to that of a group of male employees, then the group of female employees would not be paying for its fair share of the annuity plan because of the female group's greater average longevity. The Department contended that in an equal contributions-equal benefits program, a woman will receive the monthly benefit check for a longer period than a male, thereby receiving total benefits in excess of the male's, without having paid more into the fund for this offsetting advantage. According to this argument, fairness to the group of male employees requires that employers utilize sex-segregated actuarial tables leading to either unequal contributions or unequal periodic benefits. ${ }^{93}$

The Court responded that all insurance imvolves subsidies. Insurance being a risk-spreading device, the risks that fall below the average of the insured group always subsidize the risks that exceed the average risk of the group. The Court held:

[W] hen insurance risks are grouped, the better risks always subsidize the poorer risks. Healthy persons subsidize medical benefits for the less healthy; unmarried workers subsidize the pensions of married workers; persons who eat, drink, or smoke to excess may subsidize pension benefits for persons whose habits are more temperate. Treating different classes of risks as though they were the same for purposes of group insurance is a common practice which has never been considered inherently unfair. To insure the fiabby and the fit as though they were equivalent risks may be more common than treating men and women alike; but nothing more than habit makes one "subsidy" seem less fair than the other. ${ }^{94}$

In this one paragraph in Manhart, the Supreme Court summarized an argument deserving of much lengthier treatment. The argument begins with the proposition that all types of insurance, including pensions, require that predictions about the risks of the group to be insured be inade with a statistically valid basis. In order for such predictions to lead to a financially sound insurance program, the insured group must

\footnotetext{
because of or on the basis of pregnancy, childbirth, or related medical conditions; and women affected by pregnancy, childbirth, or related medical conditions shall be treated the same for all employment-related purposes, including receipt of benefits under fringe benefit programs, as other persons not so affected but similar in their ability or mability to work, and nothing in section 703(h) of this title [the Bennett Amendment] shall be interpreted to permit otherwise.
}

Pub. L. No. 95-555, 92 Stat. 2076 (1978) (codified at 42 U.S.C. $\$ 2000$ e-k). Due to the new statute the EEOC has promulgated guidelines on sex discrimination and prcgnancy. 44 Fed. Reg. 23,805 (1979) (to be codified in 29 C.F.R. $\$ 1604.10$ ).

93. Opening Brief for Petitioner, 23-26; Reply Brief for Petitioner, 16-19.

94. 435 U.S. at 710 (footnotes omitted). 
be of substantial size. ${ }^{95}$ One basis for statistically valid predictions is that, as a group, women live longer than men. ${ }^{96}$ If it could be proven that every woman will in fact outlive every man, the Title VII sex discrimination charge would not be made out. But that is not the case. In fact, the standard deviation ${ }^{97}$ from the average life expectancy is quite high for both males and females. ${ }^{98}$ While the actuarial tables imdicate that the average sixty-five year-old man will die at age eighty-two and the average sixty-five year-old woman will die at age eighty-six,, 99 individual statistics will show that eighty-four percent of the females will actually die at the same age as their male counterparts. ${ }^{100}$ The greater average life expectancy of feinales may be accounted for by the sixteen percent of the woinen and the sixteen percent of the men whose death ages do not inatch. Thus, "the effect of the actuarial grouping by sex is to compel an intra-group subsidy among women: all women are compelled to contribute inore to a retirement fund than any man is required to contribute because some women will live longer than most woinen and most inen."101 Classification by sex places a significant number of people into the wrong risk grouping, and is therefore unfair to those individuals. ${ }^{102}$ Title VII demands fairness to individuals and will not tolerate the attribution to individuals of a group an average that has so high a standard deviation that in the majority of cases, there

95. See notes 32-38 supra and accompanying text.

96. See note 34 supra. All available evidence indicates that at least part of this difference may be explained by genetic factors, but that it is also due to a number of environmental factors, such as sinoking and drinking levels, the annount of stress to which one is subjected, driving habits, and personality traits. D. MCGill, Fundamentals of Private Pensions 316 (3d ed. 1975); Gerber, The Economic and Actuarial Aspects of Selection and Classification, FORUM 1205, 1220 (1975).

97. Standard deviation is a measure of the tendency of the individual nembers of the group to differ from the average for the group. C. AMMER \& D. AMMER, DICTIONARY OF BUSINESS AND ECONOMICS 397 (1977).

98. Bernstem \& Williams, supra note 33 , at 1221-22.

99. See note 34 supra.

100. Henderson v. Oregon, 405 F. Supp. 1271, 1275 n.5 (1975); King, supra note 32, at 556-57 (quoting Professor Barbara Bergmann of Committee W of the American Association of University Professors).

101. Van Alstyne, supra notc 50, at 151.

102. The Court recognized this in a footnote in Manhart:

The Department's ... contribution schedule distinguished only imperfectly between long-lived and short-lived employees, while distinguishing precisely between male and female employees. In contrast, an entirely gender-neutral system of contributions and benefits would result in differing retirement benefits precisely "based on" longevity, for retirees with long lives would always receive more inoney than comparable employees with short lives. Such a plan would also distinguish in a crude way between male and fenrale pensioners, because of the difference in their average life spans. It is this sort of disparity-and not an explicitly gender-based differential - that the Equal Pay Act intended to authorize [under its exemption for "factors other than sex"].

435 U.S. at 713 n.24. 
will be no actual difference between the individual neinbers of the various groups. ${ }^{103}$ Indeed, it is not at all clear that Title VII will permit such attribution to individuals of group characteristics absent a showing that $100 \%$ of the members of the group possess the characteristic to be attributed to them. The solution demanded by Title VII is the elimination of classification by sex, and the use of classification by age alone ${ }^{104} \mathrm{~m}$ allocating the costs of pensions. The mandate of Manhartsex-neutral pension plans-does not require an abandonment of the risk-spreadimg principles of imsurance; it only necessitates an abandonment of the traditional sex-segregated actuarial tables. To accomplish 'this, the insurer must rely on large groupings of insureds. The larger the group, the more the risk is spread. ${ }^{105}$ Thus, because grouping by sex reduces the size of the imsured group, sucl grouping actually violates the principles of insurance as well as the requirements of Title VII. ${ }^{106}$

Thus, Manhart and the principles of insurance require that the costs of pension plans be allocated over the female group of einployees and the male group of employees on an equal basis. This allocation will result im a greater cost of a pension for inales, but this increased cost does not mean that males are "subsidizing" females. It only means that the risk of longevity is being spread over the insured group in a inanner as fair to each individual as possible where insurers and pension plans must necessarily rely on group characteristics. If the cost of

103. "If it is unjust for men to pay for the longevity of women, it is equally unjust for the 84 percent of women who die at the same time as their male counterparts to pay for the extra longevity of the remaining 16 percent." Gold 626.

104. Classification and grouping by age in employment situations is generally prohibited. 29 U.S.C. \& 623(a) (1976). However, an exemption to this prohibition exists when the employer is observing the terms of a bona fide employce benefit plan imcluding pension plans. 29 U.S.C. $\S 623(1)$ (1976), as amended by Pub. L. No. 95-256, § 2(a), 92 Stat. 189 (1978).

One could ask, however, why similar arguments are not made against age classification.

$A$ unan who retires at age sixty, with a given dollar aceumulation, will ordinarily receive a smaller [periodic] pension benefit than a man who retires at age seventy. If one cannot consider the greater life cxpectancy of the average sixty-five year old woman as compared to the average sixty-five year old man, can periodic benefits be based upon the greater life expectancy of the average sixty-year old man as compared to the average seventy-year old man? Certainly, some retirees at age sixty will have fewer post-retirement years than seventy-year old retirees. . . .

Similarly, higher automobile insurance preımums for drivers under twenty-five is [sic] not fair to the many careful young drivers. We accept these age classifications, even if they are in some degree inequitable, because either each imdividual suffers the burden at some point [as in the case of automobile insurance] or [in the case of early retirement] the individual chooses whether to subject himself to harsher conditions.

Halperin \& Gross 249-50 (footnote omitted).

105. See note 30 supra and accompanying text.

106. The reason insurers have traditionally violated the principle of large groupings by differentiating on the basis of sex was to lower the cost of pensions for inen who comprise a larger segment of the pension market than do women. See text accounpanying notes 36-38 supra. 
a pension is now greater for a male, it is not due to any unfairness to the male, but only to the fact that the male had been paying less than his fair share previously. ${ }^{107}$

\section{AFTER Manhart}

\section{A. The Necessity of Equal Benefits.}

The Manhart case involved a differential in the levels of employee contributions to a pension fund. The Court held that a defined benefit plan cannot so differentiate on the basis of sex. If Manhart is to end sex discrimination in employer-operated pension plans, then this holding must also prohibit defined contribution plans from paying smaller periodic benefits to women. If equal periodic benefits were not required, employers now operating defined benefit plans would switch over to defined contribution plans. Both unequal contributions in a defined benefit plan and unequal benefits in a defined contribution plan result from the use of the differing average life expectancies of the two sexes $^{108}$ which the Court found to be discriminatory in Manhart. If the use of such data is prohibited in determining contributions, it must also be prohibited in determining benefits. ${ }^{109}$

Aside from the imphed reasoning of Manhart, other courts and agencies have required equal benefits for the sexes in pension plans. ${ }^{110}$ In addition, the two inain administrative interpreters in the area of sex discrimination, the EEOC and the Wage and Hour Division of the Department of Labor, have issued guidelines or proposed guidelines that require equal benefits. ${ }^{111}$

\section{B. Methods of Compliance with Manhart.}

In complying with the Manhart rule of equal enployee contribu-

107. "The advantages males now enjoy rest on an unlawful system. In short, were uni-sex actuarial tables used, males would fare no worse than they would have had the retirement system been operated in a fair lawful manner all along." EEOC, Unequal Benefits Resulting From SexSegregated Actuarial Tables Are Sex Biased, 2 EMPL. Prac. GuIDE (CCH) I 6431, at 4153 (1974); accord, United States v. St. Louis-San Francisco Ry., 464 F.2d 201 (8th Cir. 1972); United States v. Bethlehem Steel Corp., 446 F.2d 652 (2d Cir. 1971).

108. See notes $34-35$ supra and accompanying text.

109. In Manhart, the Court did not specifically discuss equal benefits. The one indication, other than the logic of the matter itself, that the Court a priori considered equal benefits to be required by Title VII is in a footnote referring to "an entirely gender-neutral system of contributions and benefits . . . " 435 U.S. at 713 n.24 (emphasis added).

110. EEOC v. Colby College, 589 F.2d 1139 (1st Cir. 1978) (based on the Supreme Court's holding in Manhart); Henderson v. Oregon, 405 F. Supp. 1271 (D. Ore. 1975) (citing favorably the district court opinion in Manhart); EEOC, supra note 107, at 4153.

111. 29 C.F.R. $\S 1604.9$ (f) (1978); 43 Fed. Reg. 38,029, 32,031-32 (1978) (proposed amendment to 29 C.F.R. $\S 800.116(d))$. The Wage and Hour Division guideline cites Manhart as its authority. 
tions and equal benefits in pension plans, plan operators inust necessarily be concerned with inaintaining the financial soundness of the plan. ${ }^{112}$ Assuining the continued use of sex-segregated life expectancy tables, it still costs more to provide a pension to women as a group because of their greater average longevity. This cost must be allocated over the entire class of employees either directly or indirectly. ${ }^{113}$ At least four inethods of compliance with Manhart have been proposed that sliould help assure the financial soundness of pension plans.

1. Classification by a Combination of Traits. Solne commentators, ${ }^{114}$ recognizing that the greater average longevity of females is due partly to genetic factors and partly to environmental factors, ${ }^{15}$ have suggested that it may be permissible to use sex as a factor in determining pension costs and benefits if this were limited to the extent that the difference in longevity was due to genetic factors. To accomplish this, individuals inust also be actuarially classified according to the environinental factors, including smoking and drinking habits, weight problems, driving habits, and personality traits. ${ }^{16}$ Although such a concept was not specifically sanctioned in Manhart, the Court did factually distinguish, without comment as to consequences, the case before it from a hypothetical one where sex plus a number of other factors were used to determme an individual's longevity. ${ }^{117}$ If indeed a sexlinked genetic element in longevity could be isolated, the Supreme Court might permit a plan to differentiate between the sexes-genetics being a "factor other than sex" for the purposes of the Equal Pay Act exemption. ${ }^{118}$ Any plan inust also be based on proof that all women possess the genetic trait, so that there is little chance of a woman being classified in the wrong group. However, at the present time, medical science is unable to accurately isolate a sex-linked genetic factor im longevity or to show that sucl a factor is possessed by all women. Therefore, this alternative is not currently feasible. ${ }^{119}$

112. Although the court in Colby College followed the Supreme Court's holding in Manhart, it was skeptical whether the financial soundness of pension plans could be achieved under Manhart. 589 F.2d at $1144-46$.

113. Gold 623.

114. Halperin \& Gross 249.

115. See note 96 supra.

116. All nongenetic factors responsible for the greater longevity of women must be isolated in order to deterinine the genetic factor involved.

117. 435 U.S. at 712.

118. See notes 12-13 supra and accompanying text. Of course, even if the Supreme Court were to sanction genetics as a "factor other than sex," the Congress could statutorily override the Court, as it did with pregnancy. See note 92 supra.

119. Even if the "genetic factor" could be isolated, the multiple traits theory is unlikely to be utilized. First, the administrative costs of annuities would rise, for the means of measuring inulti- 
2. Employer-added Contributions. The above idea of predicting longevity based on age, sex and several other traits envisions a change in the actuarial methods of the pension operator. It is possible, however, to continue to operate a pension fund utilizing sex-segregated actuarial tables to predict the cost of the pension plan. It is clear that these tables will contmue to reflect the greater average longevity of women and they will contmue to demand higher contributions for a woman than for a man in order that equal benefits inay be paid without depletimg the fund. ${ }^{120}$ Since these added contributions cannot be assessed to the class of woinen employees, the added contributions must come from the employer. ${ }^{121}$ Indeed, this is how the Los Angeles Department of Water and Power has coinplied with Title VII. ${ }^{122}$

Employer-added contributions effectively spread the cost of the greater average longevity of female employees over the entire class of employees. By having the einployer make imcreased contributions for the female employees, the employer has less money to devote to the payment of present wages that could be spread over all employees. ${ }^{123}$

The one problem with the theory of employer-added contributions is that it provides a disincentive for the employer to hire women because it will cost him more in total compensation amounts to employ woinen than to employ men. If this disincentive actually induces an employer to hire employees with his eye on the gender composition of his workforce, he will violate Title VII. ${ }^{124}$ of course, this discrimination would be subtle and therefore difficult to prove in a court of law. Because of the disincentive to hire women, employer-added contributions are not the most effective way to end sex-discriminatory plans. This funding method removes an overt form of discrimination yet encourages einployers to engage in discrimination of a more subtle nature. ${ }^{125}$

ple traits would be costly. Investigation of the personal habits of each annuitant cannot help but cost more than a cursory check of gender. Indeed, the multiple traits must be constantly tabulated because the personal habits of people, unlike their sex, may change. Second, the multiple traits theory would defeat the imsurance principle of spreading risk over large groups. (See notes 30-33 supra and the accompanying text.) It would result in a number of small groups instead of a few groupings by age. Finally, by utilizing so many groups, the risk of placing someone in the wrong groups would be multiphed many times over.

120. See note 35 supra and accoinpanying text.

121. Title VII is concerned only with the amount of employee contributious and benefits. The guidelines interpreting the statute make this clear. See notes 64,72 \& 75 supra.

122. See note 47 supra.

123. Gold 622-23.

124. See note 3 supra.

125. Bernstein \& Williams, Sex Discrimination in Pensions: Manhart's Holding $v$. Manhart's Dictum, 78 Colum. L. Rev. 1241 (1978); Bernstem \& Williams, supra note 33, at 1212; Note, 
3. Unisex Actuarial Tables. Another method of equalizing employee contributions and benefits entails an alteration in the actuarial inethods used for the pension. This method is based upon unisex actuarial tables. These tables nerge the sex-segregated tables presently im use and yield an average life expectancy of a person, male or female. The average life expectancy of people derived from such a table will be somewhat above the life expectancy derived from the nuale table and somewhat below the life expectancy derived from the female table. Because the average life expectancy of a male will be greater when determined by reference to a unisex table rather than a sex-segregated table, the cost of a pension to a male will mcrease, as reflected by higher contributions or lower periodic benefits. Similarly, the cost of a pension to a woman will decrease. This is because the risk disparity ${ }^{126}$ of the unisex group is greater than for either the nale group or the female group; therefore, the average risk for the unisex group gravitates to a point between the average risk for the two sex-segregated groups. Although the risk disparity would be greater under a unisex systen, the unfairness of being placed in the wrong group would be eliminated, ${ }^{127}$ and that is the point of Title VII.

The one hidden issue here is that in using unisex tables, account nuust be made of the inale-feinale ratio in the einployer's workforce, for the higher the proportion of women in the workforce, the higher the average life expectancy of the whole workforce will be, ${ }^{128}$ and thus the total cost of the pension plan. Unisex tables, nonetheless, will accomplisli Title VII's requirenient of spreading the total cost of the plan over the entire class of employees undifferentiated by sex. The male-feniale ratio would only be involved im measuring the total cost of the pension plan, ${ }^{129}$ but not in spreading it, an idea that was fully envisioned by the Court in Manhart. ${ }^{130}$ However, suclı a system creates a disincentive for

Employment Discrimination and Tile VII of the Civil Rights Act of 1964, 84 HARv. L. REv. 1109, 1175 (1971).

126. Risk disparity is a measure of the difference between the greatest risk of the group and the least risk of the group.

127. Halperin \& Gross 249.

128. The idea of a mandated unisex annuity table has been advanced, under which label the assumption is usually made that the same annuity table would apply to different annuitant groups regardless of the proportion of males and females in them. This would not be the result; a law based on such an assumption would be analogous to well-meanmg legislation attempting to transform $\pi$ into a whole number. Benefit cost calculations would still have to take imto account differences in life spans represented by the proportion of males and females in covered groups in order to fund incurred liabilities.

King, supra note 32, at 560. The First Circuit Court of Appeals echoed this criticism of unisex tables. EEOC v. Colby College, 589 F.2d 1139 (Ist Cir. 1978).

129. Gold 627. But see Bernstein \& Williams, Sex Discrimination, supra note 125 (arguing that unisex tables can be used to measure as well as to spread the cost of pension plans).

130. 435 U.S. at 718 . 
employers who contribute to pension funds to hire women, just as does the system of employer-added contributions, ${ }^{131}$ smce total compensation costs will decrease with the number of women in the workforce. As a matter of policy, such an incentive to discriminate agaimst women should not exist.

Employers adoptimg unisex tables must use caution in setting employee contribution and benefit levels. The Equal Pay Act prohibits equalization of wages by reducmg the wage rate of any employee. ${ }^{132}$ Raising contributions of males or lowering benefits to males may constitute a reduction in the wage rate of males. If so, employer-added contributions would seem to be the only method of compliance with Manhart that utilizes an employer-operated pension plan. Of course, Title VII does not have a provision similar to that of the Equal Pay Act and the courts have not read one into the statute. ${ }^{133}$ Therefore, the acceptable means of remedying unequal treatment of the sexes in pension plans depends to solne extent on how the violation is characterized.

4. Cash Lump Sum Payments to Employees. The Court in Manhart said:

Nothing in our holding imphies that it would be unlawful for an einployer to set aside equal retirement contributions for each employee and let each retiree purchase the largest benefit which his or her accumulated contributions could command in the open market. ${ }^{134}$

The amassed contributions for each similarly situated employee will be the same regardless of sex due to the mandate of Title VII. But, as long as private imsurers use sex-segregated actuarial tables, a woman with the same amount of amassed contributions as a man will not be able to purchase an annuity with periodic benefits as great as her male counterpart, for Title VII applies only to employers, not to private insurers. The private imsurer is therefore free to engage $\mathrm{m}$ price discrimination between men and woinen. ${ }^{135}$ Since this type of system would totally

131. See text accompanying notes 124-25 supra.

132. 29 U.S.C. $\S 206(d)(1)(1976)$.

133. See note 107 supra.

134. 435 U.S. at 717-18.

135. But the Court pointed out in a footnote in Manhart that it did not mean to suggest that "an einployer can avoid its responsibilities by delegating discriminatory programs to corporate slrells. Title VII applies to 'any agent' of a covered employer." 435 U.S. at 718 n.33. Besides the agency theory, some commentators would prevent private insurers from discriminating against woinen regardless of any relationship between the employer and the insurer by using the state action doctrine; the argument being that the state regulatory bodies that oversee insurance companies cannot permit sex discrimination. Halperin \& Gross at 240; Note, Gender Classification in the Insurance Industry, 75 CoLUM. L. REv. 1381, 1394-96 (1975). 
eliminate all einployer-based discrimination, cash lump sum payments are the best way to coinply with the letter of Title VII. However, the spirit of Title VII would not be vindicated, for sex discrimination in aimuities would continue, albeit without employer involvement.

\section{CONCLUSION}

Title VII requires that employers deal with einployees on the basis of their individual attributes and not the "average traits" of their sex. Insurance principles require grouping by traits with the classification of individuals within any group according to the "average traits" of the group. Traditionally, insurers have grouped people by sex. In the area of pension plans this has meant that pensions cost more for women than for men due to the greater average longevity of women. In Manhart, the Supreme Court held that Title VII demands that einployeroperated pension plans not charge women more for a pension than inen. Of the four proposed methods of compliance with Manhart, none is well-suited to the goal of eliminating sex discrimination. Classification by a coinbination of traits is presently impossible due to the lack of inedical evidence, and the legality of such a method is by no means clearly established. Both enployer-added contributions and unisex actuarial tables provide an incentive for employers to discriminate against women in hiring, as opposed to the discrimination in coinpensation found in Manhart. Furthermore, unisex tables may be violative of the Equal Pay Act. Cash lump suni payments of contributions to einployees effectively eliminate employer sex discrimination, but leave woinen subject to discrimination by private insurers not reached by $\mathrm{Ti}$ tle VII. Clearly, Manhart has not resolved all the problems of sex discrimination in pension plans. Perhaps the problem is not so much with the civil rights laws as with actuarial primciples. ${ }^{136}$ Thus, the Supreme Court has given the insurance industry a mandate to ineasure insurance costs in a statistically valid way that does not discriminate in any manner on the basis of sex.

Gordon R. Kanofsky

136. Indeed, the First Circuit in EEOC v. Colby College, 589 F.2d 1139, 1144 (1st Cir. 1978), expressed doubts whether Manhart could be implemented without revolutionizing the insurance industry. 